\title{
Merquior - o ensaísta e sua obra
}

\author{
Antonio Medina Rodrigues
}

Eu me preparava para fazer uma recensão do último livro de Merquior, que é uma compilação de ensaios representativos de sua vida e sua obra, quando soube de sua morte. Á simples idéia de que ele não poderia mais responder com eventuais reparos e discordâncias, coisa que fazia tão bem e com tanto gosto, assaltou-me o desejo de apenas tentar uma descrição simples do ensaísta e sua obra, sem entrar na discussão de algumas de suas teses, mas mostrando sua relevância, e chamando a atenção sobretudo para a atitude mental do estilista. Eu já conhecia boa parte desses trabalhos publicados ao longo de vinte e cinco anos de atividade. Creio mesmo que, conquanto possua uma coleção de primores, aliás, como acontece em quase tudo que José Guilherme Merquior escreveu, Crítica (1964-1989) não me parece conter a melhor das antologias do autor. Não porque ele haja "barrado", como diz na "Apresentação", sua juvenília (coisa que não fez totalmente), mas porque deixou de acrescentar sua contribuição de polemista de imprensa e de autor de um belo livro de história da literatura brasileira (De Anchieta a Euclides, 1977), onde trabalhou com um registro de linguagem diferente do da maior parte de sua produção crítica, um registro pedagógico e público por excelência. Eu não deixaria de incluir mesmo algo de sua participação em debates "ao vivo", dada a extraordinária articulação de fala que demonstrava (o que é raro e até às vezes desprezado na vida intelectual brasileira, mas nem por isso deixa de ser mais importante). Teríamos, desta forma, um Merquior oral, ao lado de um Merquior mais escritivo. Dois princípios parecem ter norteado sua montagem do livro: o da evolução biográfico-intelectual e o da variedade temática, num total de trinta e um trabalhos.

Por ocasião de seu falecimento, li na imprensa tentativas de sumarizá-lo num punhado de pontos de vista, onde se pontuavam algumas extravagâncias da pessoa. Esta é uma tarefa que sempre se espera da crítica jornalística. Mas, no caso de Merquior, ela tende a deixar na sombra a importância dos traços importantes do "escritor" e do "pensador em ação”. São estes traços, afinal, que dão coloração particular ao que o ensaísta escreve e sustentam seu interesse. Sabemos que as mesmas idéias podem ser desposadas por pessoas muito diferentes e que a insistência neste caráter de generalidade "reduz" a significação particularizadora do estilo, quando não a elimina totalmente. Se quisermos colher o "pessoal", é necessário ver como é que estas idéias se casam com a atitude compositiva. Para dar um exemplo, se todas as idéias de Marx se "encarnassem" na linguagem de Bertrand Russell, duvido que a imagem do marxismo fosse a mesma. E a diferença estaria onde? Estaria no "modo concreto" da idéia, no "perfil físico" do conceito, coisas que só se dão no gesto da escrita. Por isso é que acho injusto considerar Merquior, como constantemente se faz, pelo traço estritamente "temático" ou pela mera síntese das opiniões. Neste ponto me lembro da reação de Borges, que, interpelado sobre sua simpatia para com Cortázar, respondeu que gostava dele independentemente de qualquer opinião, pois "nada lhe parecia mais superficial que uma opinião".

Ora, quando não fosse pelos argumentos ou pelas opiniões, a obra de Merquior no
ANTONIO MEDINA RODRIGUES é professor de Língua e Literatura Grega da Universidade de São Paulo. 
mínimo exige a consideração que merece um homem que colaborou para mudar substancialmente o panorama da prosa ensaística brasileira. Merquior criou uma expressão nova em nosso meio, e os instrumentos que utilizou não se circunscrevem ao estilo ágil e à frase incisiva e sintética. Merquior inventou um meio particular de exprimir a reflexão no Brasil, e isso não deve ser entendido apenas como uma questão d'art d'écrire, é sobretudo uma questão de produção pessoal de pensamento (que $\hat{\epsilon}$, enfim, o que lhe querem negar os que só vêem em sua trajetória uma existência meramente formal e livresca).

Qual o sentido mais importante de sua escrita? A meu ver, a resposta desta questão começaria por se considerar a comunhão histórica que Merquior manteve com uma certa tradição da polêmica no Brasil, e que, no caso particular dele, eu chamaria traço "paidêutico" (este adjetivo, que não está na maioria dos dicionários, refere-se, sobretudo por etimologia, ao caráter intrinsicamente educacional de uma cultura, caráter que tende a modelar o cidadão com as exigências mínimas de socialidade e bom gosto, caráter que costuma polemizar "conservadoristicamente" contra os arrojos da modernidade de todas as épocas). Aqui não nos queremos referir ao suposto conservadorismo de Merquior, mas ao traço comunicativo, educacional e reativo que transparece no fundo de seus textos. Ele, que não exerceu o magistério, mas a diplomacia, foi antes de tudo um homem interessado em expor e debater idéias, num diapasão tenso e cromatizado de linguagem, mas que também é de fulgurante common sense (e talvez por aí se explique um pouco sua antipatia para com os diversos idioletos intelectuais que ciclicamente nos chegam de Paris, e a que ele chegou mesmo a prestar algum tributo juvenil). Com tudo isso, Merquior foi o que melhor representou entre nós a clarté funda e laminar. O texto de Merquior jamais esconde, jamais se medusa em qualquer estratégia intraneurótica. Sob esse aspecto, registre-se, não tinha nenhuma superstição. Vinha a público discutir abertamente o que quisesse e aquilo para que o desafiassem.

Mas o traço paidêutico de Merquior está inspirado também na formação enciclopédica. Sabia demais, e queria comunicar o que sabia. Era livre-pensador, não dependia do decoro universitário, que, sabemos, é às vezes uma barreira nessa necessária ligação que deve haver entre a vida do saber e o retorno comunitário. Lembro-me que certa vez um discutível psicanalista "pop" reprovou-lhe, diante das câmeras, um certo "terrorismo bibliográfico", pedindo-lhe que se soltasse mais, que saŕsse dos livros, enfim, que se mostrasse como um Merquior "humano"... ao que este respondeu, com toda segurança (para maior terror do psicanalista), que tinha vindo ao programa para debater idéias, sobretudo psicanálise, pois, dizia, sua figura pessoal não tinha interesse algum... Merquior defendia como poucos os direitos da pessoa, mas tinha verdadeira alergia ao que ele achava fossem os descaminhos do sujet.

Mas não foi, repetimos, com sua paidêutica de polemista, um fenômeno isolado. De certa forma, ele descende de uma surda auto-rejeição de nosso estatuto provinciano (cuja fonte mais antiga talvez esteja na poesia culturalmente ressentida de Cláudio Manuel da Costa) e que em nossa prosa seria representado sobretudo por grandes polemistas como Tobias Barreto, ou Sívio Romero, ou Carlos de Laet ou José Oiticica. Com este último, Merquior tem um parentesco ainda maior, quer no anarquismo (que em Oiticica foi político, e nele foi intelectual), quer na oposição ferrenha a toda síntese política "fechada", quer na alergia que ambos tiveram pelas teses do estruturalismo (sim, nos anos 40, Oiticica já conhecia as idéias de Trubetzkói e sobre elas polemizava com Sílvio Elia...) ou ainda na desconfiança que ambos nutriram contra certas realizações do Modernismo nas artes. Mas Oiticica, belo gramático e mediano poeta, foi voltado à causa operária, e Merquior, como se diz, defendeu valores do liberalismo e do capitalismo (quando não se diz, pelo atropelo do concreto e do abstrato, que defendeu os "capitalistas"...). Esta última imagem, piorada pelo estereótipo de "direita", com que assacavam contra ele, é o que ficou de mais evidente para a imensa maioria que não freqüentou seus livros ou que só reteve algumas das críticas que fazia às esquerdas. Fortaleceu essa imagem o ter servido em governos militares, como diplomata de carreira.

Atinar, entretanto, com a imagem mais verossímil de Merquior não é terçar argumentos para que ele, depois de morto, tenha suavizada a dureza do estereótipo, se em vida ele fez questão de responder a todos seus críticos e desafetos com uma pontualidade e fidalguia em geral desconhecida entre nós. Aliás, para avaliar estas miuçalhas e mesquinharias, o interessado deverá pressurosamente recorrer à competência duvidosa do biografismo político, e olhe lá que talvez se surpreenda com o contrário do que procure... 
O que importa é que todo problema "político" séria e nitidamente levantado pela figura de Merquior, queiram ou não seus detratores, está limitado à pura atividade intelectual e polêmica. Se quisermos saber alguma coisa relativa ao homem, fora da moeda fácil dos estereótipos, teremos de confiar nos meandros quase sempre deformantes das crônicas de gabinete, que rondam a ficção, ou nos limitarmos despreconcebidamente a ler e discutir o que Merquior escreveu e ensinou. Nenhum dos trinta e um trabalhos contidos em Crítica (1964-1989) é "de direita". No máximo, defendem uma postura neo-iluminista ou liberal, que é o lugar, aliás, para onde começam inclinar-se muitos dos que atacavam Merquior exatamente por ter idéias desse tipo.

Depois, o que é mais estimulante em Merquior não é a dimensão "positiva" ou aquilo que ele defende, mas aquilo que ele critica. Sabe-se, por exemplo, que Merquior defendia a modernidade contra as investidas do modernismo. Noutros termos, defendia a infra-estrutura, a industrialização do capitalismo moderno, contra o que ele considerava o retrocesso irracionalista de ụma boa parte da representação artística contemporânea. A antropologia política de Merquior tendia a desconfiar de toda construção teórica que se afastasse um pouco do cânon iluminista do século XVIII. Aceitava e praticava a "negatividade" como método de heurese, porque era por instinto um anarquista, mas nunca aceitou essa "negatividade" como dimensão ontológica do que quer que fosse. Evolução política e humana, sim, mas com civilidade ilustrada.

É curioso como esta posição, defendida implícita ou explicitamente ao longo de sua vida, não contrasta com seu anarquismo temático e com sua ciclópica leitura de tendências por vezes tão díspares. Ao que me parece, a verdadeira paixão de Merquior não teria sido tão teorética como se pensa, foi antes paixão de saber e de exprimir. Tinha lá suas idéias enraizadas, mas estas só funcionavam como minimum racional, como baliza demarcatória que seu instinto opunha contra qualquer sugestão de irracionalismo. Ou do que ele julgasse irracionalismo. E estas idéias-limite, a que se acrescenta, obviamente, o neoliberalismo, funcionariam no conjunto de seu trabalho de ensaista como "princípios" de evidência prática. Aliás, não aceitava nenhum princípio político que não tivesse uma dimensão imediatamente prática, visível e portanto confiável. Isto estava entranhado em seu modo de ser. Seu liberalismo também está de tal forma encarnado em seu modo polimorfo e atípico de escrever, que tudo nele se passava como se o estilo reclamasse sua própria imagem fundante, que era aquela que em última análise aplaudia o progresso, abominava as superstições políticas e exaltava a liberdade irrestrita (mais uma vez, o estilo reproduz o homem).

Só esse liberalismo é que podia dar consistência ao anarquismo temático de Merquior, e temático não só no sentido de focalização de um tipo de objeto (poesia, romance, economia, política, pintura, ideologia, estética, etc.), mas temático também no sentido predicativo, de atribuição de valores (dá um certo estruturalismo, que depois combateu, bem como sugestões fortes de Luckács, Heidegger, Walter Benjamin).

Por outro lado, esse anarquismo, que no plano das idéias se socorre de um neoliberalismo instintivo, pelo lado da pessoa não exprime tanto inconstância como certa incapacidade de envolver-se ou certo horror a mostrar-se como sujet, como portador de uma subjetividade (e sua alergia à psicanálise pode ter mesmo essa origem). Exatamente por isso é que Merquior nos dá sempre impressão de um vigor "cerebral" comprometido em moto-contínuo com idéias e com impressões explosivas de leitura, em que, por sinal, ele não tem paralelo na crítica brasileira. Merquior teve o gênio do pormenor lancinante e da pertinência. Seu discurso é em grande parte ur:a calistênica de tradução dos discursos mais complicados da modernidade e nisso ele ainda é o grande pedagogo sem giz e sem quadro-negro (não só pelo que "traduz", mas tombém pela maneira lapidar com que o faz). Seu discurso institui as miradas críticas mais penetrantes, e logo surpreendentemente as abandona, em favor de outras. Sabia fazer períodos longos, mas seu "peso" estava todo na energia da frase que colhe várias coisas ao mesmo tempo, mais ou menos como costumam proceder certos pintores, que, com fortes e poucas pinceladas, fazem jorrar um sentido compacto e complexo. Tinha a mente concisa. Sua frase não lembra, corro acontece na maior parte da grande ensaística de uma geração anterior a sua, o movimento suave e particularizante de um poema sinfônico, tecido peça por peça, mas lembra certa impressão instantânea de profundidade da pintura barroca: assaltanos e logo o olhar é cativado por outra coisa. O gesto sintático de Merquior nunca programa o objeto ao longe ou, se o faz, sempre o faz por superposição de blocos, que nunca chegam a um perfil final "arredondado". Tudo nele tende a um aparente disjecta membra.

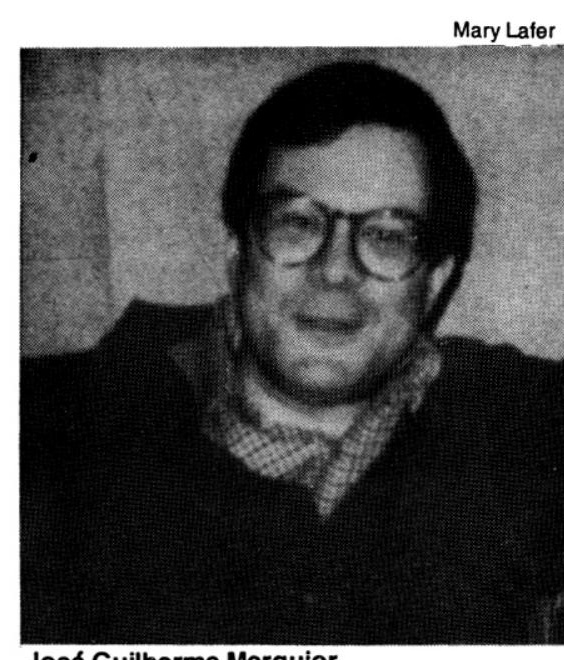

José Guilherme Merquior 
Enfim, o trabalho espiritual de Merquior se pautou sempre pelo látego do aforismo, aquele aforismo que ganhou cidadania filosófica sobretudo com Nietzsche, mas que depois de Nietzsche se teria irreconciliado totalmente com a técnica de exposição do ensaio universitário. Diferentemente do aforismo paulista, que é cômico e grafêmico, e do carioca, que é patético e "tolstoiano", o aforismo crítico de Merquior tenta uma pegada incisiva no objeto, sem fraque e sem cartola, sem modismos, sem preliminares ou ademanes. Merquior era um bruto que punha todo seu s angue e força na predicação. Está para nascer, entre nós, alguém que tenha aberto mais gavetas do que ele. Deu pancada para todo lado nessa confraria estamental que é por vezes o exercício do saber entre nós. Que é isto senão uma forma primorosa e paidêutica de doar-se? Que é isto senão intensa e jovial transferência do self para o objeto? Foi, sim, um gênio dispersivo, faltou-lhe aquela "idéia fixa" que leva aos umbrais da verticalização e às vezes da monotonia. Não fazia o tipo do "profundo", mas tinha idéias profundas e as atirava ao papel numa penada. Num dos ensaios em que tentou "heideggerizar" - "O lugar de Rilke na poesia do pensamento" -, soube fazê-lo muito melhor do que os que tentaram fazê-lo sincera e ingenuamente no Brasil, mas deixa transparecer que está numa camisa-de-força temporária.

O processo básico da operação ensaística de Merquior segue o circuito "compreensão orbital-integração-explosão crítica". O reparo que se lhe pode fazer é que ele não erigiu sua paixão sobre o caule de uma idéia "de que surgissem indutivamente as folhas de todas as outras". Mas Merquior era por índole um dedutivo, sobretudo no sentido de que não era o chorrilho da vida que lhe ditava progressivamente os pensamentos, não era a "negatividade" do mundo, como acontece sobretudo na experiência intelectual auto-intitulada "de resistência". Por isso ele só poderia mesmo entregar-se ao mundo dos livros, que lhe cobraram a vida. Curiosamente, neste sentido Merquior não está longe do formalismo, que tanto combateu.

Eu desconfio mesmo que Merquior, fora daqueles princípios que convizinhavam com sua personalidade, quais sejam, o individualismo, o liberalismo e as "luzes", não acreditava em nenhuma idéia em particular a ponto de fazer dela a pauta espiritual de sua vida, que é o que costuma acontecer com seu antípoda, o pensador de cátedra. Mas, por isso mesmo, deve-se pagar a ele o tributo de ter elaborado entre nós um "modo diferente de fazer filosofia", como ponderou J. A. Giannotti. Não sei se de fato Giannotti pensou na razão acadêmica, ao discriminar essa diferença, mas o certo é que o que disse implica remeter, nos seus limites, para a cena do julgamento socrático, de que o pensador universitário seria uma pálida sombra. Pois, de fato, o pensador acadêmico bebe a vida toda a voluntária cicuta da pesquisa e da sondagem "de vida", em que se transforma seu estudo. Mas, se isso lhe garante um escaninho na ética do saber, nem por isso lhe será garantido um pequeno lugar na história dos acertos. E, aliás, o pior não é isso, mas sim o fato de que os erros do saber são apenas verdadeiramente lamentáveis quando "induzem" confrarias de pensamento e politização esclerótica. Charles Sanders Peirce, um gênio que viveu mais fora do que dentro da órbita universitária americana, observava que por vezes um homem dedica sua vida inteira à comprovação de uma idéia falsa. E as instituições universitárias, como se sabe, são muito lentas na correção de seus erros, porque, afinal, entre o saber e sua ética se instalam quase sempre os indefectíveis ditirambos de enobrecimento ad hoc. Eis por que um dos remédios críticos mais eficientes, para este estado de coisas, é acolher sem preconceitos o que vem de fora, sobretudo aquilo que represente alteridade ou multiplicação de pontos de vista - e por que não dizer? - aquilo que venha de fora com poder paródico. Fazer com que um objeto seja visto de muitos pontos de vista é uma forma de despolitizar o objeto ou despassionalizá-lo. Fazer com que a solenidade do objeto caia sob a espécie do humor é fazer com que nossa percepção dele se perceba como saturada, como cansada, sendo, portanto, capaz de investigar outras modalidades. Um dia se verá que esta é uma das dívidas que temos para com o irrequieto e já saudoso José Guilherme Merquior. 